\title{
Woody Species Diversity and Structure of Agroforestry and Adjacent Land Uses in Dallo Mena District, South-East Ethiopia
}

\author{
Bikila Mengistu ${ }^{*}$, Zebene Asfaw ${ }^{2}$ \\ ${ }^{1}$ Sinana Agricultural Research Center, Bale-Robe, Ethiopia \\ ${ }^{2}$ Wondo Genet College of Forestry and Natural Resources, Hawassa University, Shashamane, Ethiopia \\ Email: ^bikilamengistu@gmail.com
}

How to cite this paper: Mengistu, B. and Asfaw, Z. (2016) Woody Species Diversity and Structure of Agroforestry and Adjacent Land Uses in Dallo Mena District, SouthEast Ethiopia. Natural Resources, 7, 515534.

http://dx.doi.org/10.4236/nr.2016.710044

Received: May 29, 2016

Accepted: October 17, 2016

Published: October 20, 2016

Copyright $\odot 2016$ by authors and Scientific Research Publishing Inc. This work is licensed under the Creative Commons Attribution International License (CC BY 4.0).

http://creativecommons.org/licenses/by/4.0/ (c) (i) Open Access

\begin{abstract}
Sustainable farming practice that utilizes and conserves biodiversity, reducing negative impacts of agriculture on biodiversity and provides wood and energy to local community is a good solution to reduce deforestation and forest degradation. This study was carried out in Dallo Mena district of Bale zone to identify woody species diversity in homegarden agroforestry practices, shade grown coffee agroforestry practices and adjacent natural forest, and to show how land use and management practice determine the plant species diversity. The study site was selected based on spatial analogue approach. In each land use, a plots of $10 \mathrm{~m} \times 10 \mathrm{~m}$ size was drown by using systematic sampling method following the transect line. A total of 36 sample plots were sampled along the transect line laid down inside each land uses. In each plot, woody species were counted and the diameter and height of trees and shrubs were measured. Based on this inventory a total of 39 woody plant species which are about $23,10,15$ woody plant species were recorded from natural forest, shade grown coffee agroforestry and homegarden agroforestry practices respectively. These species were classified belonging to 24 families. The Shannon Wiener diversity index used to estimate species diversity ranged from 0.14 to 2.54 with a mean of 1.47 . Also $21 \%$ woody species similarities were observed between those three land uses. The result shows that both agroforestry practices (shade grown coffee and home garden agroforestry practices) and adjacent natural forests are conserving several woody species diversity in its system.
\end{abstract}

\section{Keywords}

Agroforestry, Conservation, Diversity, Practice, Woody Species

\section{Introduction}

Natural forest is one of the richest ecosystems in plant species diversity and used as a 
home of many and diversified plant species. Natural forest has wide ecological and environmental values and is a source of biodiversity [1]. Ethiopia is also one of the richest countries in having plant species diversity. The geographical location of Ethiopia covers wide agro-climatic zones and important center of biological diversity. This wide ecological condition of Ethiopia has created diverse and conducive environments for the development of a variety of flora. There are about 7000 different flowering plants grown in Ethiopia, out of which about $12 \%$ of them are endemic for the country [2].

The rapid expansion of agriculture is one of the greatest threats for the losses and degradation of forest biodiversity. This uncontrolled expansion of agriculture has led to deforestation and forest degradation, which in turn led to food insecurity and poverty in many parts of the world including Ethiopia. However, there are evidences that indicate sustainable farming practices, like agroforestry, utilize and conserve biodiversity, improve environmental quality and limit agricultural expansion into natural forests as well as the negative impacts of agriculture on biodiversity [3].

Agroforestry is a dynamic, ecologically based, natural resources management system that, through the integration of trees on farms and in the agricultural landscape, diversifies and sustains production for increased social, economic and environmental benefit for land users at all levels [4]. Agroforestry is the production of trees and of non-tree crops or animals on the same piece of land and provide diverse output from the same land units. These land use types were conserve different types of plant species diversity in pieces of land and minimizes the impacts of community in the natural forest.

Homegarden agroforestry practices are among the agroforestry systems with the potential to harbor native forest biodiversity. Homegardens are a place where a clearly bounded piece of land immediately surrounding the dwelling house is cultivated with a mixture of perennials and annuals [5]. According to [6], homegarden agroforestry in the Ethiopian highlands hosts higher woody species diversity than their nearby natural woodlands or forest lands by conservation of diverse native plant species. This high species diversity ecosystem provides important ecological services such as nutrient recycling, soil and water conservation, and reduces environmental deterioration. In Ethiopia homegarden agroforestry is the most common practices which are familiar to small holder farmers [7].

A shade grown coffee agroforestry practice is one of the land uses that contain various types of plant species diversity. As the name indicates it contains various types' of shade tree species and coffee shrubs as the major component. Due to the high income source, coffee based agroforestry practices are strongly developed and cultivated by many farmers. Because of the reduction of land and the need to increase income from coffee monoculture system, the introduction of multi-purpose timbers species in to this system is a good system to get different benefits simultaneously. As [8] reported many small coffee farms around the world incorporate trees as part of the production system, as wind breaks, for land scaping around the home and to protect the coffee plants from excessive sun and high temperature. In Ethiopia the coffee shade based agroforestry practices also conserve various native woody species [9].

Agroforestry and other land uses of Dallo Mena districts are providing various envi- 
ronmental as well as economical benefits for the community. However, there was no information in relation to comparing the agroforestry and adjacent natural forest in woody species diversity conservation. Most of the reports which are studied in Dallo Mena districts are focus on the plant species diversity of the natural forest. Also there are very few studies focusing on the plant diversity potential of agroforestry practices [10]. But the status of woody species diversity in natural forest and agroforestry land uses is not well studied. Therefore, this study designed to show the contribution of agroforestry and adjacent natural forest of Dallo Mena district for woody species diversity conservation and to compare the amount of woody species diversity conserved in those land uses.

\section{Material and Method}

\subsection{Study Area}

Dallo Mena district is located in Oromia regional state, Bale zone and covers about 461,665 hectares. It lies between latitudes $5^{\circ} 51^{\prime} \mathrm{N}$ and $6^{\circ} 45^{\prime} \mathrm{N}$, and longitudes $39^{\circ} 35^{\prime} \mathrm{E}$ and $40^{\circ} 30^{\prime} \mathrm{E}$ (Figure 1). The altitude ranges from 1314 to 1508 m.a.s.l. The major soil type of the woreda is Nitosol which is the dominant soil in the area [11]. Climatically the area characterized by bimodal rainfall with the main rainy season occurring early March through June and the short rain late September through November. The mean annual rainfall is $986.2 \mathrm{~mm}$ and the mean annual temperature is $22.5^{\circ} \mathrm{C}$.

According to 2007 Population and Housing Census of Ethiopia, the population number of Dallo Mena was 89,670 [12]. The indigenous inhabitants of the area are

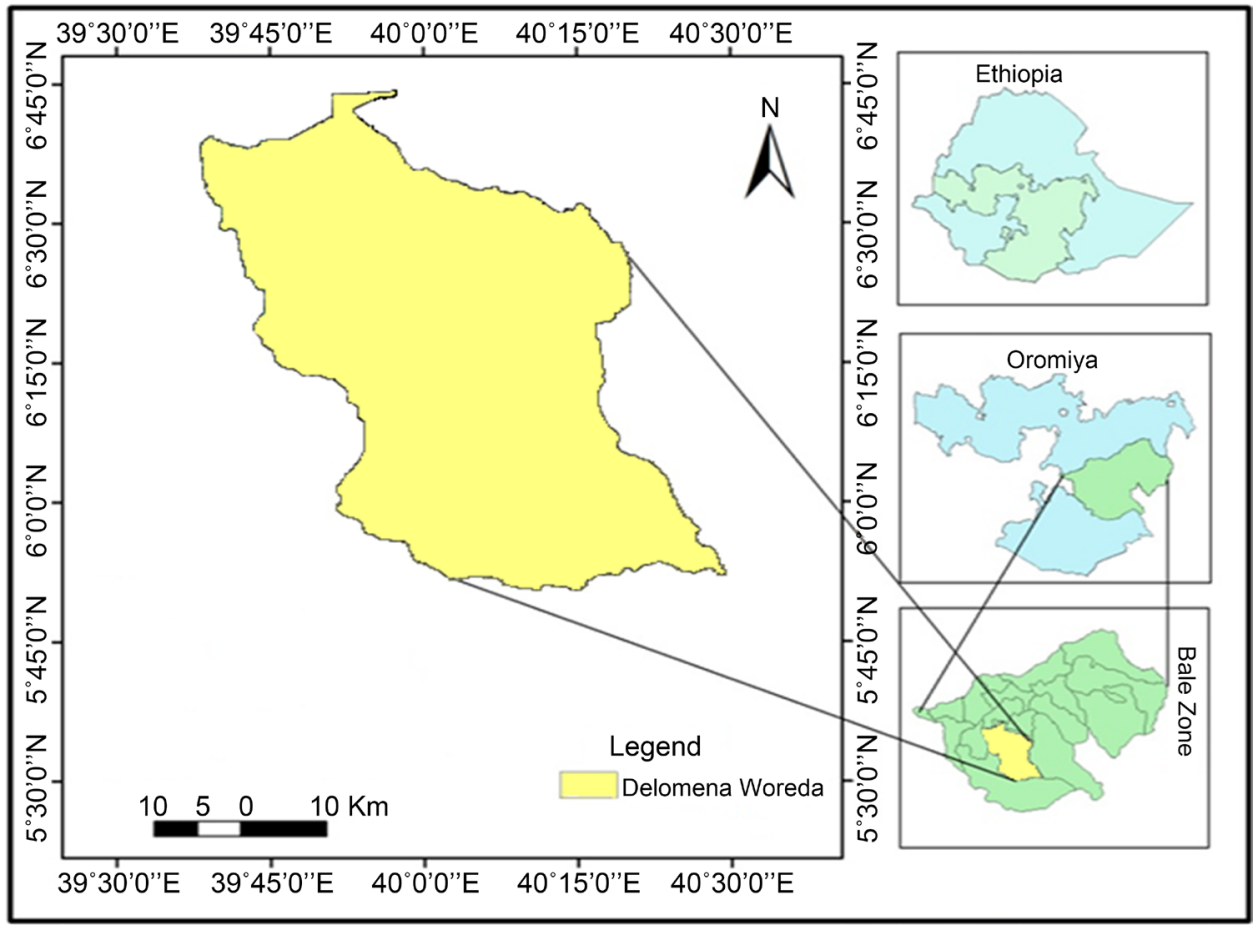

Figure 1. Map of Dallo Mena Woredas of Bale zone, Southeast Ethiopia. 
primarily Oromo peoples. In addition to this few ethnic groups Gurage and Amhara are also settled in the area. Dallo Mena forest has mixed broad-leaved and coniferous montane forest species. According to [13] classification, this forest is categorized as Dry Evergreen Afromontane forest type. The dominant farming activities in Dallo Mena woreda is mixed farming systems, livestock and subsistence crop production farming.

\subsection{Method}

\subsubsection{Sampling Techniques}

Before staring the sample collection, reconnaissance survey was carried out to identify the study site, verify the land use type and sampling method. The land use were selected based on its arrangement, vegetation structure and the size of land uses. The three land uses are found adjacent to each other in stratified manner in the order of natural forest, shade grown coffee and homegarden. Due to the similarity of topography, climate and land use history of all land uses which are originated from the forest land, special analog approach was chosen for site selection. The sites differed only in the land use type and soil management practices.

A systematic sampling method was applied to locate the sample plots to assess woody species diversity and composition. For all land uses the data was collected following the transect line. The distance between each transect and plot in each land uses were about $500 \mathrm{~m}$ and $400 \mathrm{~m}$ respectively. In the process of data collection the first transect line and the first plot were selected purposely inside the land uses. For this study a plot size of $10 \mathrm{~m} \times 10 \mathrm{~m}$ was used to encompass all woody seedling, sapling and tree grown in side plot.

\subsubsection{Sampling Design}

\section{Plant Identification and Biomass Estimation}

On each plot woody species seedlings $(<2.5 \mathrm{~cm}$ diameter and height $<1 \mathrm{~m})$, saplings and shrub (2.5 - $5 \mathrm{~cm}$ diameter and height $1-2 \mathrm{~m})$ and trees and shrub $(\geq 5 \mathrm{~cm}$ diameter and height $\geq 2 \mathrm{~m}$ ) were recorded by complete count of each [14] [15]. For all woody species having $\mathrm{DBH} \geq 5 \mathrm{~cm}$ the diameter at breast height $(\mathrm{DBH}$ at $1.3 \mathrm{~m})$ were recorded. For the coffee shrubs, the diameter was measured at $15 \mathrm{~cm}$ from the ground (D at $15 \mathrm{~cm})[16]$.

The diameter and height was measured by using Caliper, Diameter tape and Hypsometer. Species identification for common species was done in the field by using different plant identification keys as references [17] [18] [19] [20]. But for the less common species identification was done by taking plant sample specimen.

\subsection{Data Analysis}

\section{Floristic Composition, Population Structure and Diversity}

The floristic composition and structure of the agroforestry systems and adjacent natural forest were calculated in terms of size, relative frequency, relative density, relative dominance, basal area, and importance value index.

\section{Diversity Indices}


A diversity index is a mathematical measure of species diversity in a community. Diversity indices provide more information about community composition than simply species richness (i.e., the number of species present); they take the relative abundances of different species into account. Diversity indices provide important information about rarity and commonness of species in a community. For this study the diversity indices of the sampled land use types were calculated by using Shannon diversity which is very widely used index for comparing diversity between various habitats [21].

The Shannon diversity index is calculated as:

$$
H^{\prime}=-\sum_{i=1}^{S} p_{i} \ln p_{i}
$$

where, $H^{\prime}=$ Shannon-Wiener index of species diversity

$s=$ number of species in community

$p_{i}=$ proportion of total abundance represented by $i^{\text {th }}$ species

Evenness:

Species evenness is a diversity index, a measure of biodiversity which is used to measure the homogeneous distribution of tree species in sample plot [22]. The evenness of a population was calculated by;

$$
E=\frac{H^{\prime}}{H_{\max }}=\frac{H^{\prime}}{\ln S} \text { with } H_{\max }=\ln S
$$

where, $E=$ Evenness

$H^{\prime}=$ Calculated Shannon-Wiener diversity

$H_{\max }=\ln (\mathrm{s})$ [species diversity under maximum equitability conditions]

$S=$ the number of species,

$P_{\mathrm{i}}=$ proportion of individuals of the $I^{\text {th }}$ species or the proportion of the total

Species

\section{Simpson's diversity Index:}

Simpson's diversity index was also used for this study. Simpson's diversity index is the most sensitive to changes in more abundant species and hence places more weight on the most abundant species in the community. The Simpson's diversity index was derived from probability theory and it is the probability of picking two organisms at random which are of different species [23]. Simpson's diversity index can be represented by;

$$
\text { Simpson's index of diversity }=1-(D)^{2} ; D=\frac{n}{N}
$$

where $D=$ Simpson's index

$n=$ The total number of organisms of a particular species

$N=$ The total number of organisms of all species

\section{Similarity Indices $\left(\mathrm{S}_{\mathrm{s}}\right)$ :}

Similarity indices measure the degree to which the species composition of different systems is alike. Many measures exist for the assessment of similarity or dissimilarity between vegetation samples or quadrates. The Sorensen similarity coefficient is applied to qualitative data and is widely used because it gives more weight to the species that 
are common to the samples rather than to those that only occur in either sample [24]. The Sorensen coefficient of similarity $\left(\mathrm{S}_{\mathrm{s}}\right)$ is given by the formula:

$$
S_{s}=\frac{2 a}{2 a+b+c}
$$

where, $S_{\mathrm{s}}=$ Sorensen similarity coefficient.

$a=$ number of species common to both samples.

$b=$ number of species in sample 1 .

$c=$ number of species in sample 2 .

\section{Multiple-Site Similarity Indices $\left(\mathrm{S}_{\mathrm{s}}\right)$ :}

The similarity of woody species diversity among the three land use types were analyzed by using a multiple-site similarity index through the use of a multiple-site similarity measure. This method was used because similarity measures have restriction that is limited to pair wise comparisons even in a multiple-site study and this method overcomes this problem of covariance between pair wise similarities in a multiple site study [25]. This index was defined as:

$$
\text { MSSI }=\frac{a b+a c+b c-a b c}{a+b+c}
$$

where, $M S S I=$ multiple site similarity index

$$
\begin{aligned}
& a=\text { number of species found in NF } \\
& b=\text { number of species found in SC } \\
& c=\text { number of species found in HG } \\
& a b=\text { number of species common to NF and SC system } \\
& a c=\text { number of species common to NF and HG systems } \\
& b c=\text { number of species common to SC and HG systems } \\
& a b c=\text { the number of species found in the three systems }
\end{aligned}
$$

\section{Basal area/Dominance:}

Basal area is the cross-sectional area of woody stems at breast height. It measures the relative dominance (the degree of coverage of a species as an expression of the space it occupies) of a species in a forest. Basal area was calculated for each woody species with diameter $\geq 2.5 \mathrm{~cm}$ and calculated as:

$$
B A=\frac{\pi\left(D B H^{2}\right)}{4}
$$

where, $\pi=3.14$

$$
\begin{aligned}
& B A=\text { basal area }\left(\mathrm{m}^{2}\right) \\
& D B H=\text { diameter at breast height }(\mathrm{cm}) \\
& \text { Relative dominance }=\frac{\text { Dominance of a species }}{\text { Dominance of all species }} \times 100
\end{aligned}
$$

\section{Density:}

The density of woody species is one of the most important structural parameters to be considered during vegetation data analysis. Density was calculated by summing up all stems across all sample plots and converting into hectare basis. 


$$
\begin{gathered}
\text { Density }=\frac{\text { Total number of individuals }}{\text { Sample area }(\text { ha })} \\
\text { Realtive Density }=\frac{\text { Total number of individuals of a species }}{\text { Total number of individual of all species }} \times 100
\end{gathered}
$$

\section{Frequency:}

Frequency is defined as the probability or chance of finding a species in a given sample area or quadrant [26]. Thus, it shows the presence or absence of a given species within each sample plot. Two frequency values were computed for each woody species encountered within the study plots: the absolute frequency and the relative frequency;

$$
\begin{aligned}
& \text { Frequency }(\%)=\frac{\text { Frequency of a species }}{\text { Total number of sample plot }} \times 100 \\
& \text { Realtive Frequency }=\frac{\text { Frequency of a species }}{\text { Frequency of all species }} \times 100
\end{aligned}
$$

\section{Important Value Index (IVI):}

The IVI of a species is used to express the relative ecological significance of the species in the forest ecosystem. It was calculated by summing up the relative dominance, relative density and relative frequency of the species [26]. It indicates the significance of species in the system. It is calculated as follows:

$$
\text { IVI = Relative Frequency + Relative Density+Relative Dominance }
$$

The plant species diversity data were analyzed by using PAST paleontological statistical software for biodiversity. Mean comparison of the four systems in plant species diversity were tested by least significant difference (LSD) test at $\mathrm{P}<0.05$ by using SAS statistical software version 9.1.3.

\section{Results}

\subsection{Woody Species Diversity}

\subsubsection{Species Diversity and Frequency}

Overall, 39 woody plant species were recorded from natural forest (NF), homegarden agroforestry practices (HG) and shade grown coffee agroforestry practices (SC). Out of this, 23 species were recorded from the natural forest while 25 were from adjacent agroforestry land uses (10 from shade grown coffee and 15 from homegarden) respectively. The entire recorded species were belonging to 24 families. From the overall plant family categorization, Rutaceae and Myrtaceae are families with relatively higher number of species. Coffea arabica, Mangifera indica and Saxifraga hederifolia were the most frequently observed woody species in SC, HG and NF which are belonging to Rubiaceae, Anacardiaceae and Saxifragaceae families respectively. The number of individual woody species recorded at HG, NF and SC were 335, 194 and 1548 respectively. For coffee shrub, the highest numbers of individuals were observed in the shade grown coffee agroforestry practice (Table 1 ). In the homegarden agroforestry practice, farmers manage both exotic (46.7\%) and native trees/shrubs species (53.3\%). 
To assess species diversity Shannon, Simpson and evenness indices were employed in this study. In terms of Simpson and Shannon diversity indices there is no significance difference between the two agroforestry practice (HG and SC), but both are significantly different from NF (Table 2).

In the natural forest, the overall frequency of occurrence of woody species varied between 1 - 56 in the surveyed plot. Saxifraga hederifolia (56), Rhus ruspolii (23) and Lepidotrichilla volkensii (17) were the most frequently observed woody species. These species accounted for $29 \%, 11.9 \%$ and $8.8 \%$ of the plant community. Species like Allophyllus abyssinicus, Flacourtia indica, Carissa spinarum and Commiphora habessinica were less frequently encountered than the other woody species (Figure 2).

Table 1. Number of individual woody species and coffee shrubs recorded in natural forest (NF), shade grown coffee (SC) and homegarden agroforestry (HG) land uses of Dallo Mena Woreda.

\begin{tabular}{cccc}
\hline System & Woody Species & Coffee Shrubs & Total Abundance \\
\hline NF & 194 & - & 194 \\
SC & 35 & 1513 & 1548 \\
HG & 233 & 102 & 335 \\
\hline
\end{tabular}

Table 2. Mean Simpson, Shannon and Evenness diversity indices among the three land uses (natural forest, shade grown coffee and homegarden) in Dallo Mena Woredas of Bale.

\begin{tabular}{cccc}
\hline & & \multicolumn{2}{c}{ Mean } \\
\cline { 2 - 4 } System & Simpson (1-D) & Shannon (H') & Evenness (J) \\
\cline { 2 - 4 } & $0.237^{\mathrm{b}}$ & $0.447^{\mathrm{b}}$ & $0.537^{\mathrm{b}}$ \\
$\mathrm{HG}$ & $0.617^{\mathrm{a}}$ & $1.168^{\mathrm{a}}$ & $0.721^{\mathrm{ab}}$ \\
$\mathrm{SC}$ & $0.308^{\mathrm{b}}$ & $0.466^{\mathrm{b}}$ & $0.812^{\mathrm{a}}$ \\
\hline
\end{tabular}

Means with the same letters across column are not significantly different $(\mathrm{P}>0.05)$ with respect to the system; $\mathrm{NF}=$ Natural Forest, $\mathrm{SC}=$ Shade grown coffee and $\mathrm{HG}=$ Homegarden.

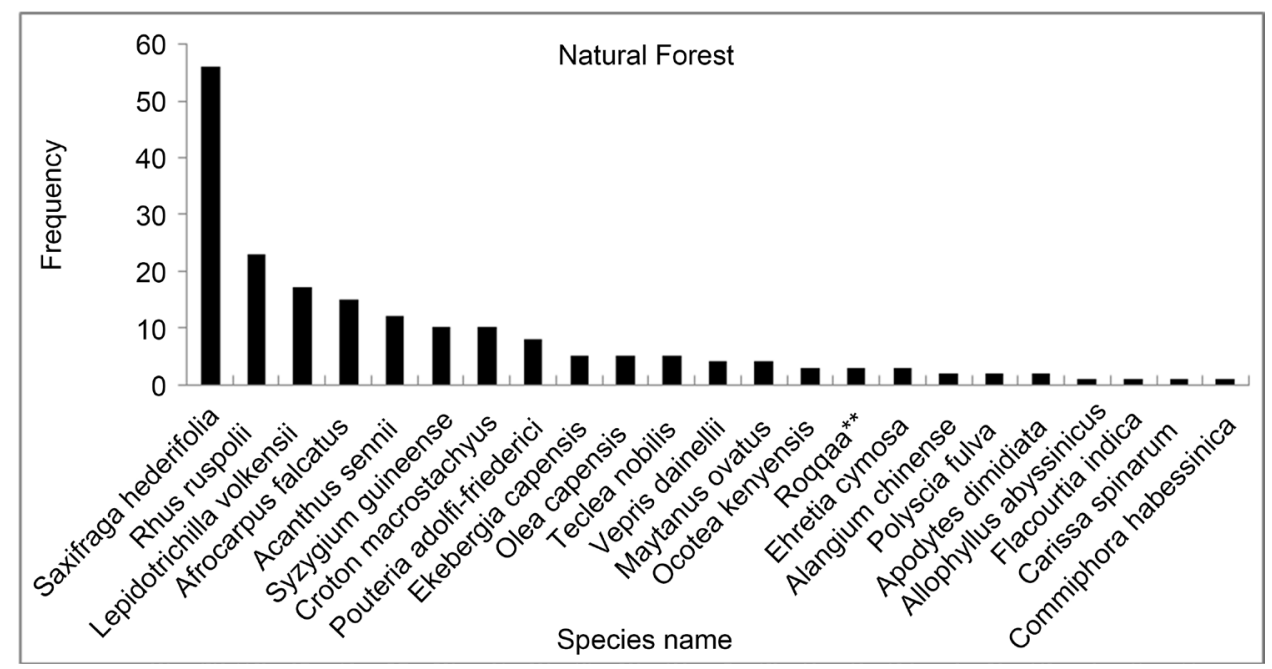

Figure 2. Overall frequency of woody species in the natural forest of Dallo Mena Woredas of Bale Zone. 
For shade grown coffee agroforestry practice, the most frequently observed woody species was Coffea arabica (92\%) followed by Afrocarpus falcatus (Figure 3).

Woody species frequency in the homegardens was in the order of: Mangifera indica (36.7\%), C. arabica (30.5\%) and Carica papaya (13.7\%) for most frequent category, and Citrus grandis, Ehretia cymosa, Jatropha curcus and Mimusops kummel for less frequent categories (Figure 4). The studied homegardens are dominated by fruit species hence can be classified as fruit tree based homegarden agroforestry practice.

\subsubsection{Woody Species Similarity Indices}

The similarities in woody species composition were compared among the land uses (Table 3 ). The highest similarity in woody species compositions $(24.2 \%)$ was recorded between homegarden and shade grown coffee, while the lowest $(9.5 \%)$ was recorded



Figure 3. Overall frequency of woody species across the shade grown coffee agroforestry practice of Dallo Mena Woredas of Bale Zone.

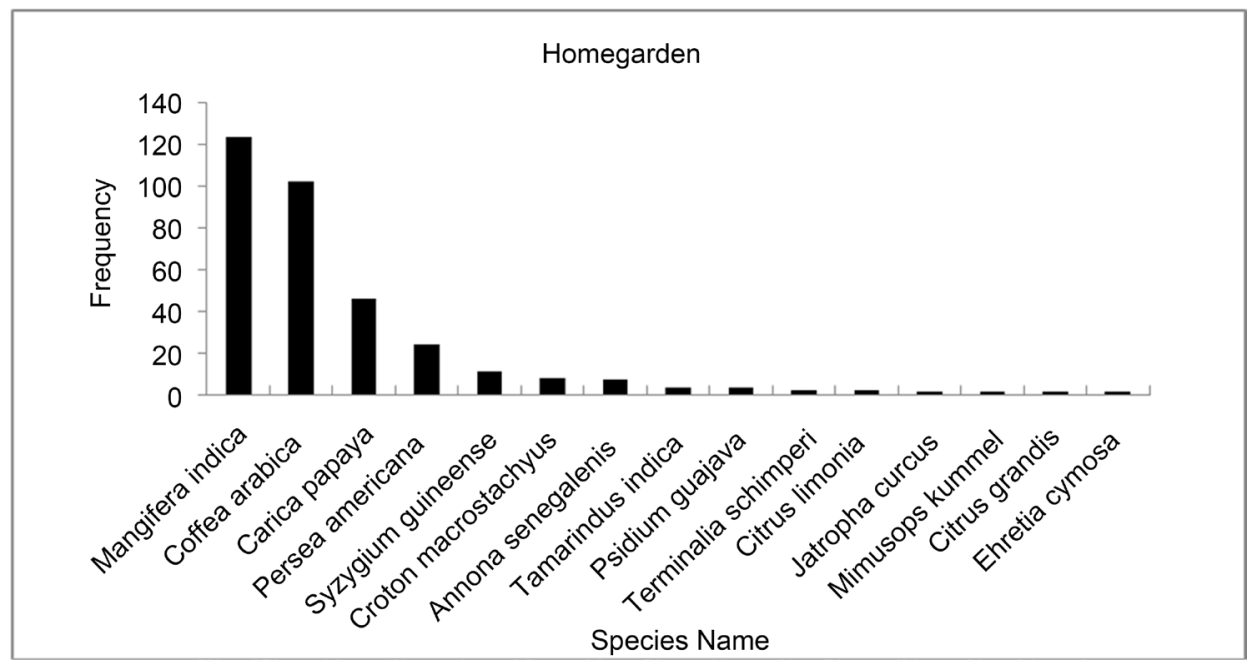

Figure 4. Overall frequencies of woody species across the homegarden based agroforestry practice of Dallo Mena Woredas of Bale. 
Table 3. Similarity index of woody species among the land uses.

\begin{tabular}{cc}
\hline Land Use Type & Similarity (\%) \\
\hline Natural Forest vs Shade Grown Coffee & 23.3 \\
Natural forest vs Homegarden & 9.5 \\
Shade Grown Coffee vs Homegarden \\
Natural Forest vs Shade Grown Coffee vs \\
Homegarden
\end{tabular}

between natural forest and homegarden. Syzygium guineense, Afrocarpus falcatus, Croton macrostachyus, Ocotea kenyensis and Polyscia fulva woody species were common to NF and SC with $23.3 \%$ similarities. Whereas, Croton macrostachyus, S. guineense and Ehretia cymosa were common for NF and HG with 9.5\% similarity. S. guineense, Croton macrostachyus, Persea americana, Psidium guajava and C. arabica are species commonly grown both in the SC and HG land uses having $24.2 \%$ similarity. About 21\% species were overlapping between the NF, SC and HG.

\subsubsection{Importance Value Index}

Species with higher IVI among NF, SC and HG are different. The five most important woody species with the highest IVI's is presented in Table 4. Of all species, $S$. guineense (77.57), C. arabica (142.79) and Mangifera indica (98.95) were the top ranking in natural forest, shade grown coffee and homegarden, respectively. The top five highest IVI species contribute about $60.22 \%, 86.44 \%$ and $80.77 \%$ of the total population in NF, SC and HG land uses respectively (Table 4 ).

\subsection{Density and Population Structure of Woody Species}

A total of 2077 individual woody species were recorded from all sample plots of natural forest, shade grown coffee agroforestry and homegarden agroforestry land uses. The highest individual woody species were recorded from homegarden agroforestry practices and the lowest were from shade grown agroforestry practice. Saxifraga hederifolia and Rhus ruspolii are the most abundant woody species with the lower diameter class $(<5 \mathrm{~cm})$ in natural forest. Where as the major woody species with highest diameter class $(>35 \mathrm{~cm})$ were $S$. guineense, Ocotea kenyensis and Pouteria adolfi-friederici. The graphical descriptions of the frequency distributions of woody species among each diameter class were inverted J-shaped graph for NF and HG, and broken inverted J-shaped graph for SC (Figure 5).

The overall mean value in $\mathrm{DBH}$, height and density were significantly $(\mathrm{P}<0.05)$ different among all land uses. The higher mean DBH were observed in the SC (55.55 \pm 9.83). Whereas the lowest mean DBH were observed in the HG (24.09 \pm 1.64$)$. From the three land uses the highest height were recorded in NF $(23.32 \pm 2.37)$. The overall mean value of woody species density of the three land uses were significantly $(\mathrm{p}<0.05)$ different from each other. The highest woody densities were observed in HG (164.68 \pm 47.35) and the lowest were in SC $(37.30 \pm 13.21)$ (Table 5). But for BA there is no significant difference among all land uses. 
Table 4. The top five woody species with the highest IVI values in the natural forest, shade grown coffee and homegarden agroforestry practice of Dallo Mena Woredas of Bale.

\begin{tabular}{ccc}
\hline System & Species Name & IVI \\
\hline \multirow{3}{*}{$\mathrm{NF}$} & Syzygium guineense & 77.57 \\
& Saxifraga hederifolia & 42.39 \\
& Afrocarpus falcatus & 23.28 \\
& Rhus ruspolii & 19.02 \\
& Pouteria adolfi-friederici & 18.41 \\
& Coffea arabica & 142.79 \\
SC & Syzygium guineense & 35.94 \\
& Afrocarpus falcatus & 35.32 \\
& Croton macrostachyus & 31.45 \\
& Ficus sur & 13.81 \\
& Mangifera indica & 98.95 \\
HG & Persea americana & 47.78 \\
& Coffea arabica & 41.31 \\
& Carica papaya & 39.15 \\
& Annona senegalenis & 15.13 \\
\hline
\end{tabular}


Figure 5. Frequency distributions of woody species by diameter class in Dallo Mena Woredas of Bale. Diameter class in cm: 1, 0 - 5, 2, >5 - 10, 3, >10 - 15, 4, >15 - 20, 5, >20 - 25, 6, >25 - 30, $7,>30-35,8,>35$.

For Coffee shrub woody species among shade grown coffee and homegarden agroforestry practices, there is no significant difference in mean diameter size $\left(\mathrm{d}_{15}\right)$ and basal area. But for coffee height and density values are significantly $(\mathrm{P}<0.05)$ different from each other. The result shows that the largest heights were observed in HG $(4.13 \pm 0.16)$. The value of coffee density at SC $(1869.14 \pm 421.93)$ is significantly higher than the value for HG $(283.33 \pm 154.62)$ (Table 6). 
Table 5. Stand Structure Mean ( \pm SE) of woody species in three land use system (NF, SC and HG) in Dallo Mena Woreda of Bale.

\begin{tabular}{ccccc}
\hline \multirow{2}{*}{ System } & \multicolumn{4}{c}{ Mean $( \pm$ SE $)$} \\
\cline { 2 - 5 } & Dbh $(\mathrm{cm})$ & Height $(\mathrm{m})$ & Density $\left(\mathrm{ha}^{-1}\right)$ & BA $\left(\mathrm{m}^{2} \mathrm{ha}^{-1}\right)$ \\
\hline HG & $24.09( \pm 1.64)^{\mathrm{b}}$ & $8.74( \pm 0.54)^{\mathrm{b}}$ & $164.68( \pm 47.35)^{\mathrm{a}}$ & $2.42( \pm 0.54)^{\mathrm{a}}$ \\
$\mathrm{NF}$ & $41.75( \pm 11.99)^{\mathrm{ab}}$ & $23.32( \pm 2.37)^{\mathrm{a}}$ & $109.63( \pm 41.85)^{\mathrm{ab}}$ & $3.22( \pm 1.73)^{\mathrm{a}}$ \\
$\mathrm{SC}$ & $55.55( \pm 9.83)^{\mathrm{a}}$ & $17.25( \pm 3.47)^{\mathrm{a}}$ & $37.30( \pm 13.21)^{\mathrm{b}}$ & $3.79( \pm 1.25)^{\mathrm{a}}$ \\
P-Value & $<0.0001$ & 0.0006 & $<0.0001$ & 0.7457 \\
\hline
\end{tabular}

Means with the same letters across column are not significantly different $(\mathrm{P}>0.05)$ with respect to the system; $\mathrm{SE}=$ Standard error, $\mathrm{DBH}=$ Diameter at breast height and $\mathrm{BA}=$ Basal area.

Table 6. Mean $( \pm$ SE) of population structure of coffee shrub species in the two agroforestry practices (SC and HG) in Dallo Mena Woreda of Bale.

\begin{tabular}{ccccc}
\hline \multirow{2}{*}{ System } & \multicolumn{3}{c}{ Mean $( \pm$ SE $)$} \\
\cline { 2 - 5 } & Dsh $(\mathrm{cm})$ & Height $(\mathrm{m})$ & Density $\left(\mathrm{ha}^{-1}\right)$ & BA $\left(\mathrm{m}^{2} \mathrm{ha}^{-1}\right)$ \\
\hline HG & $5.30( \pm 0.28)^{\mathrm{a}}$ & $4.13( \pm 0.16)^{\mathrm{a}}$ & $283.33( \pm 154.62)^{\mathrm{b}}$ & $0.29( \pm 0.03)^{\mathrm{a}}$ \\
SC & $5.45( \pm 0.21)^{\mathrm{a}}$ & $3.60( \pm 0.16)^{\mathrm{b}}$ & $1869.14( \pm 421.93)^{\mathrm{a}}$ & $0.30( \pm 0.02)^{\mathrm{a}}$ \\
P-Value & 0.6603 & 0.0196 & 0.0028 & 0.8309 \\
\hline
\end{tabular}

Means with the same letters across column are not significantly different $(\mathrm{P}>0.05)$ with respect to the system; $\mathrm{SE}=$ Standard error, $\mathrm{DSH}=$ Diameter at stump height and BA $=$ Basal area.

\section{Diameter Distribution of Woody Species with Highest IVI}

Natural Forest

In natural forest woody species with the top five highest IVI were $S$. guineense, $S$. hederifolia, A. falcatus, $R$. ruspolii and Pouteria adolfi-friederici (Table 4). In terms of population structure of $S$. guineense, individuals with the lower and middle diameter classes was absent (Figure 6(a)). On the other hand population structure of $S$. hederifolia was observed in less than $25 \mathrm{~cm}$ dbh class (Figure $6(\mathrm{~b})$ ). The number of individuals of $A$. falcatus are present in the lowest two and highest diameter classes. But the medium diameter classes were absent (Figure 6(c)). For Rhus ruspolii the number of individuals were only limited to the smallest diameter class (Figure 6(d)). In the case of Pouteria adolfi-friederici, few lower classes and significant higher diameter class individuals were observed. But the medium diameter class was absent (Figure 6(e)).

\section{Shade Grown Coffee Agroforestry}

In shade grown coffee agroforestry practice the top five woody species with highest IVI are C. arabica, S. guineense, A. falcatus, Croton macrostachyus and Ficus sur (Table 4). There is fair population structural distribution for $C$. arabica bush having highest number of individuals with diameter range of $5.6-7.0 \mathrm{~cm}$ followed by $1.4-2.8$ $\mathrm{cm}$ diameter class (Figure 7(a)). For S. guineense, A. falcatus and Ficus sur only individuals of higher diameter class were recorded (Figure 7(b), Figure 7(c), Figure 7(e)). In the case of Croton macrostachyus only few individuals of medium and higher diameter class were observed (Figure 7(d)).

\section{Homegarden Agroforestry}

In homegarden agroforestry practice the top five woody species with higher IVI are 


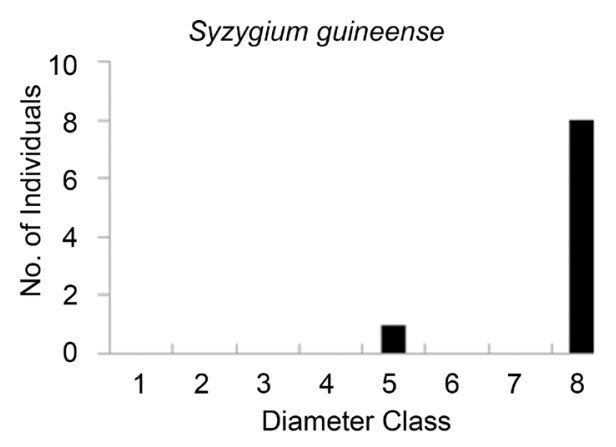

(a)

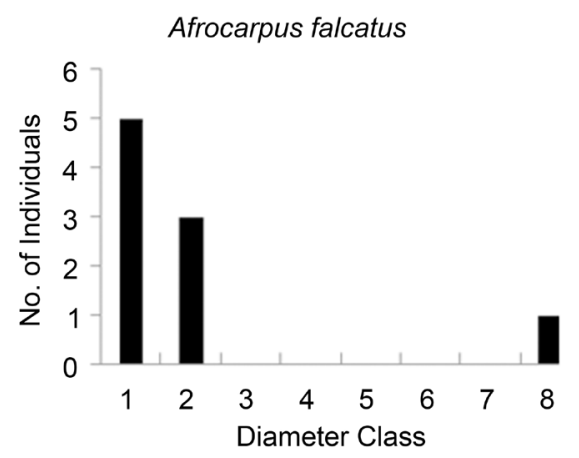

(c)

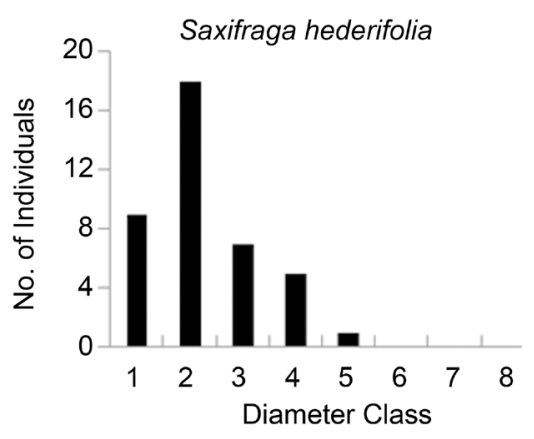

(b)

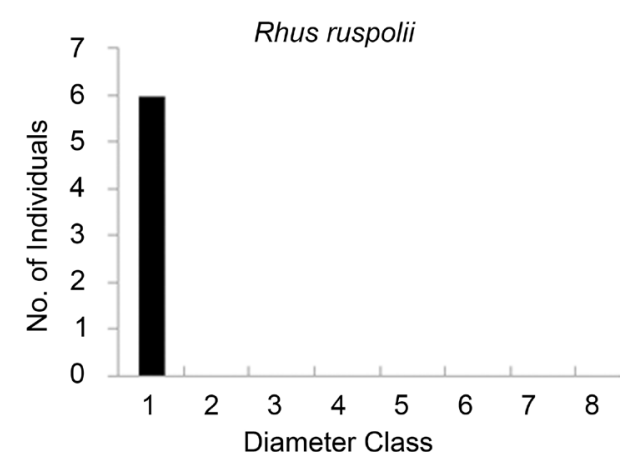

(d)

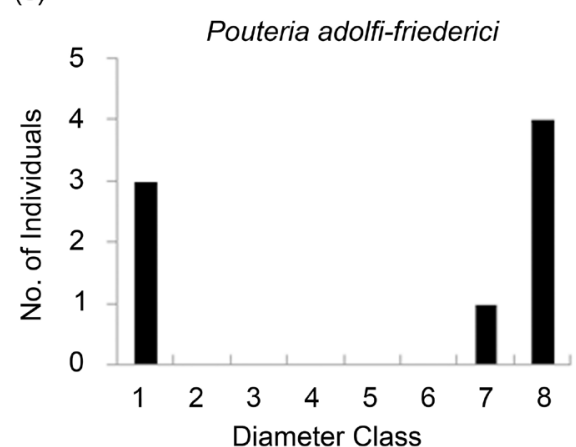

(e)

Figure 6. Diameter class distribution of woody species with the highest top five IVI in NF. Diameter for trees in cm: $1,0-5,2,>5-10,3,>10-15,4,>15-20,5,>20-25,6,>25-30,7,>30$ $35,8,>35$.

indicated in Table 4. Mangifera indica was one of the frequently observed woody species. The overall population structure of this species represented with few individuals in smaller diameter and larger diameter sizes, and with higher larger number of individuals in the medium diameter class (Figure 8(a)). For Persea americana large amount of individuals were observed in the medium and larger diameter class species. For this species the lower diameters class individuals were absent (Figure 8(b)). For C. arabica larger amount of individuals were recorded in the medium diameter classes. But the number of individuals was declined as the diameter increased (Figure 8(c)). In the case of Carica papaya higher amount of small diameter class were observed (Figure 8(d)). For Annona senegalenis higher number of individuals was recorded in lower and medium diameter class (Figure 8(e)). 


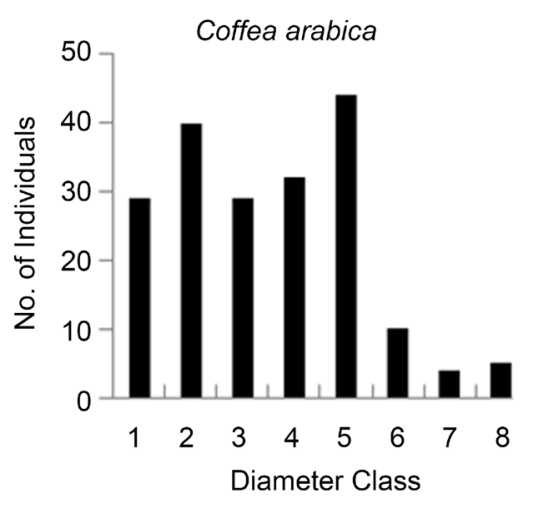

(a)

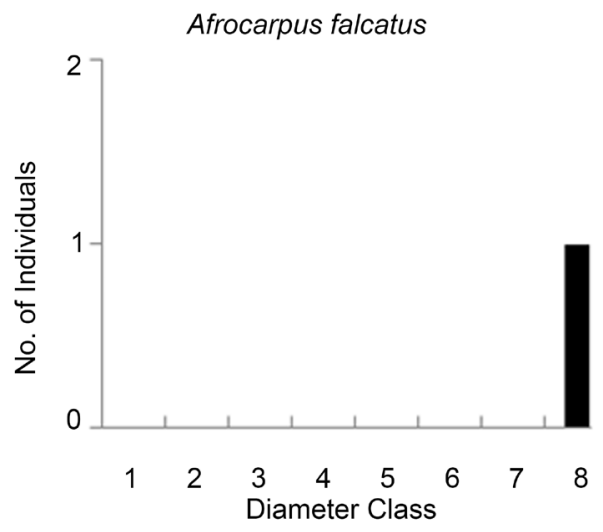

(c)



(b)

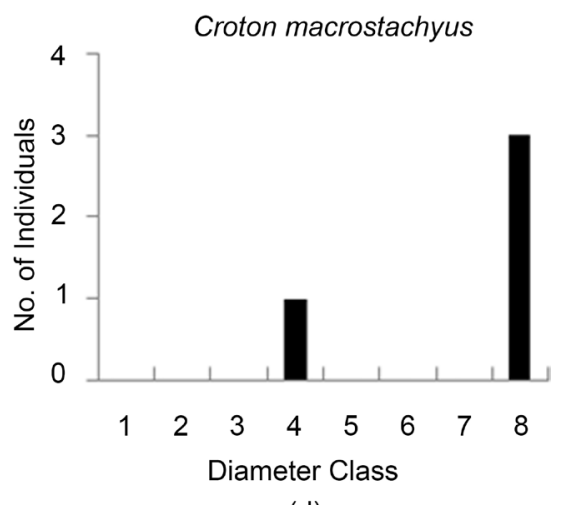

(d)

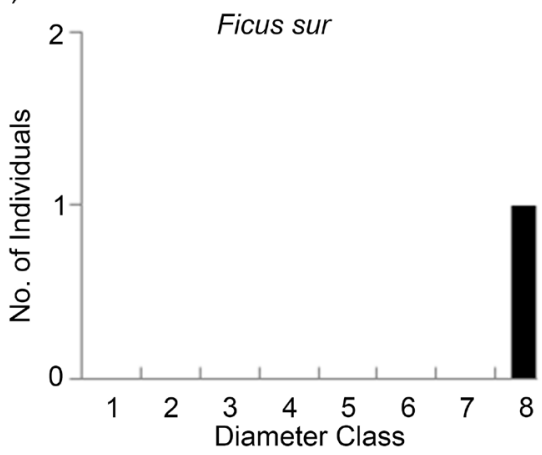

(e)

Figure 7. Diameter class distribution of woody species with the highest top five IVI in SC. Diameter for trees in cm: $1,0-5,2,>5-10,3,>10-15,4,>15-20,5,>20-25,6,>25-30,7,>30-$ $35,8,>35$ and diameter class for coffee in $\mathrm{cm}: 1, \leq 1.4,2,>1.4-2.8,3,>2.8-4.2,4,>4.2-5.6$, $5,>5.6-7.0,6,>7.0-8.4,7,>8.4-9.8,8,>9.8$.

\section{Discussion}

\subsection{Woody Species Diversity and Composition}

Different land uses encompasses various types of biological diversity. Among several of them, woody species are one of the dominant types basically grown naturally or manually. From a total 39 woody species diversity recorded during this inventory, about $23,10,15$ species were recorded from natural forest, shade grown coffee and homegarden agroforestry practices. Among all land uses higher species richness were recorded 


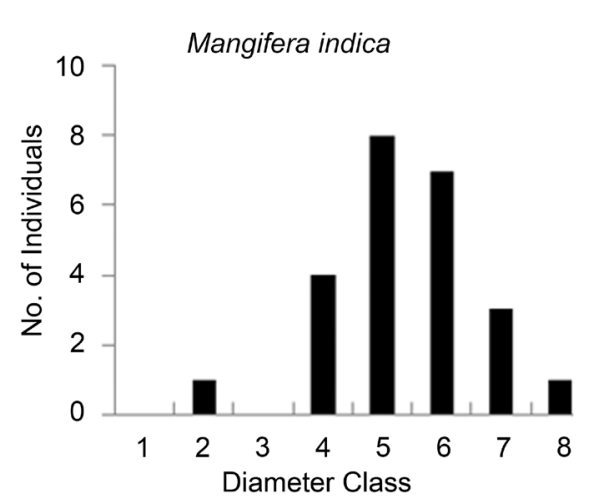

(a)

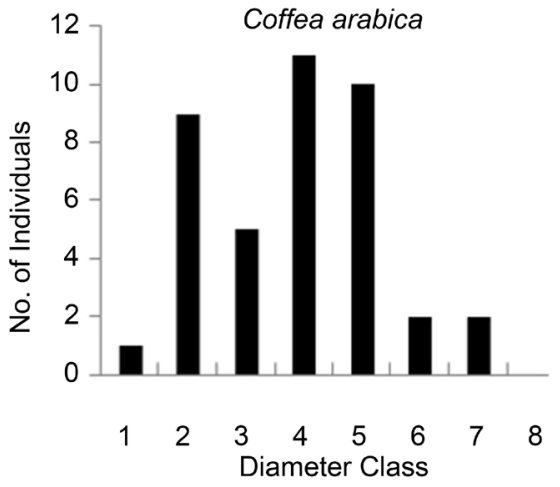

(c)

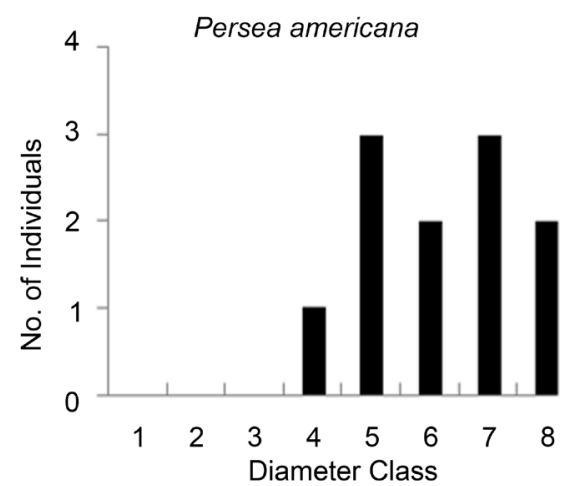

(b)

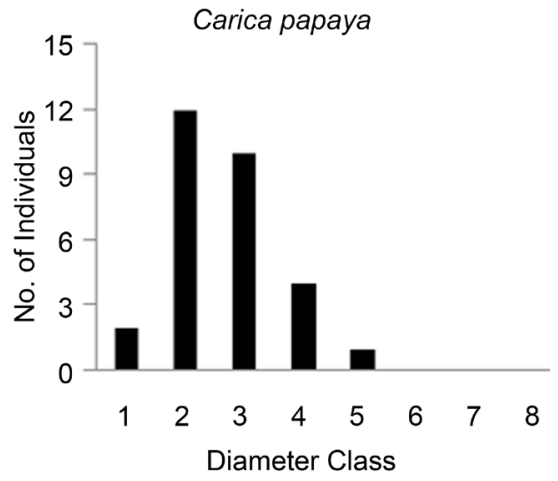

(d)



(e)

Figure 8. Diameter class distribution of woody species with the highest top five IVI in HG. Diameter for trees in cm: 1, $0-5,2,>5-10,3,>10-15,4,>15-20,5,>20-25,6,>25-30,7,>30-$ $35,8,>35$ and diameter class for coffee in $\mathrm{cm}: 1, \leq 1.4,2,>1.4-2.8,3,>2.8-4.2,4,>4.2-5.6$, $5,>5.6-7.0,6,>7.0-8.4,7,>8.4-9.8,8,>9.8$.

in the NF forest $\left(\mathrm{H}^{\prime}=1.168\right)$. Due to farmers' activity to increase the land use efficiency and due to intensive thinning of other plant species in order to reduce competition from the coffee lower species richness were recorded from both agroforestry practices. This activity might affect and limit the number of woody species which are grown in system.

The degree of species similarity between natural forest and shade grown coffee agroforestry, natural forest and homegarden agroforestry, and shade grown coffee and homegarden agroforestry is about $23.3 \%, 9.5 \%$ and $24.2 \%$. This implies that the degree of 
species similarity within the three land use system is low and different woody plant species diversity was observed within each land use. The multiple-site similarity index of natural forest, shade grown coffee and homegarden agroforestry was found to be $21 \%$. This indicates that, the three land uses have less overlapping species with each other. This could be explained by the fact that farmer intensive species selection for different use and coping strategies for constraint facing them. For example, in case of homegarden agroforestry practices due to land size shortage and irrigation facilities farmers preferred high market demanded species which are more interested on fruit species and high market value species than native species. For shade grown coffee agroforestry practice and natural forest due to the nature of the land and its closeness to each other they share some species together. Generally due to the above mentioned reasons the species similarity index of the three land uses of the area is very less. This less spices overlapping of the land uses are shows that the degree the land uses which are supports each other are less. These shows that the levels of agricultural land escape to conserve the native woody species which are grown in the natural forest are relatively less. This implies that still there are great pressure on the natural forest to satisfy wood consumption of the community.

When we see the overall species composition of the system, the natural forests were dominated by few pioneer species which are very dominant in area. But the composition of middle aged and regeneration structure of woody species is that much not promising. It is only dominated by few old aged (matured) trees which cover the upper canopy. Most of the trees which are grown in this system are very huge indigenous species with larger diameter size, height and canopy coverage. In case of shade grown coffee agroforestry practice the system is covered by very few woody species. The type of shade plant species are vey limited and only covered by over populated coffee shrubs. But when we observe the overall status of the woody plant structure most of the plant in this system are higher DBH class shade tree species. This is due to the factor that shade trees are the major component of coffee production of the area and the tree are conserved for the longer period of time. This larger diameter size species takes larger space and create great pressure on coffee plants through resource computation. In addition to this the continuity of this important woody species is under question. Also in order to increase the productivity of the system this matured higher diameter size species must be replaced by other new species. Homegarden agroforestry practice is also conserving a number plant species. But due to high market demand for vegetables the farmers concentrated only on the short rotation vegetables. But fruit trees are one of the dominant woody species which are grown in area. This farmer's direction will change their interest to focus on short rotation exotic species. This will affect the number of native woody species conserved in the farmer's field.

\subsection{Population Structure and Importance Value Index}

From all system the highest mean DBH was observed in shade grown coffee agroforestry practice $(55.55 \pm 9.83 \mathrm{~cm})$. This is due to the factor that in the coffee production 
process the tree species which are important for shade are purposely selected and conserved for the longer period of time. Due to selective thinning very few or limited tree species are grown on the larger area without competition. While the lowest DBH size was observed in the homegarden agroforestry practice $(24.09 \pm 1.64 \mathrm{~cm})$. This is due to farmers' intensive tree selection, the tree characteristics, and high resource competition within the system. As we know farmers are very sensitive for the land and very much selective for the tree grown on their field. There for due to this factor most of the trees grown in their field are fruit tree species which are not that much larger in diameter. In addition to this, farmers are cut matured and aged tree species which grown in the farm for the construction (timber) purpose and to replace by other new productive tree species.

In the case of height, the highest and lowest size were recorded in the NF and HG land uses $(23.32 \mathrm{~m}$ and $8.74 \mathrm{~m}$ ) respectively. This is due to the reason that NF is the free growing area and the tree grows without any human influence which affects the height growth. In the case of SC $(17.25 \mathrm{~m})$ due to the shade purpose the height of the trees are not managed. But for HG in order to reduce the shade and minimize light computation from the under growth plants the height of the trees are managed (pruned) repeatedly. In addition to this most of the trees which are grown in the farmers filed are multi-purpose tree species which used as animal fodder. This all factor affects the height growth.

Homegarden agroforestry practice is the highest in terms of woody species density per hectare $\left(164.68\right.$ trees $\left.\mathrm{ha}^{-1}\right)$. This is due to farmer's day to day activity in order to maximize the land use efficiency to increase their income. In this study area the average homegarden sizes of the land which are hold by each farmer are very limited ( $0.31 \mathrm{ha})$. Due to this limitation farmers incorporate different types of plant species on their farm. In other way the amount of tree density in the shade grown coffee agroforestry practice is relatively low. This is due to farmers' intensive selective tree growing and gives priority for the coffee plant only. Also this lower density of shade tree species is due to the selective removal of other plant species to promote and to produce suitable environment for coffee development and selective management of shade tree for their ecological and economical values. In addition to this the intensive soil management for coffee shrubs is also damages the regeneration and growth of plant species of the system. All this reasons shows that the tree density is depend both on the intensity of management and biophysical conditions. For BA there is no significant difference among all land use.

Due to the variation of main target of the land uses, the coffee density of shade grown coffee agroforestry practices (1869.14 trees $\mathrm{ha}^{-1}$ ) was significantly different and higher than that of HG (283.33 trees ha $\left.{ }^{-1}\right)$. That is the main objective of coffee farm is only coffee production but in HG it contains other types of annual and perennial plant species. In addition to this, the mean coffee height of HG $(4.13 \mathrm{~m})$ was higher than that of SC $(3.60 \mathrm{~m})$. This is due to light competition with other tree species which are grown together in the HG and due to higher computation of over populated coffee shrub in 
the SC.

For IVI, species with higher IVI are varied and depend on the systems. In the case of agroforestry practice the species importance is depend on the product value of the species. For example in shade grown coffee agroforestry practice woody species with the highest IVI are $C$. arabica and few other shade tree species. In Homegarden agroforestry practice woody species with highest IVI are fruit tree species and other high market value species. According to this study species with high IVI is associated with the land uses and based on farmer's species preference. When we see the overall IVI of the whole system, in all land uses more than half of IVI is covered by very few limited species. In the case of natural forests, species with higher IVI is linked with those species which are dominant and well adapted in that agroecology. Where as in the case of agroforestry practices species with higher IVI is associated with framers species preference and product value. The interest of farmers for selection of species is linked with species market demand and service value. The highest IVI species of the natural forest land uses were covered by five pioneer species which are highly dominant in the area. For homegarden agroforestry practices the highest IVI value is covered by fruit tree species which provide higher income for the farmers. Where as in the case of shade grown coffee agroforestry practice, about large percent of the practice were covered by coffee shrub and other important shade tree species which are highly familiar and positive interaction with coffee plants.

If we see the status of each individual species separately within the land uses, from the five higher IVI woody species of the NF, $S$. guineense is the one which are in problem with no seedling and sapling. For $P$. adolf-friederici even if it is disturbed there is also in seedling stage. $S$. hederifolia and $A$. falcatus is relatively species with promising future. Also abnormal distributions of Rhus ruspolii were observed in the system with only in the seedling stage. For SC from all species $C$. arabica is species with good status. But due to the absence of seedling and sapling stages the futurity of the rest species ( $S$. guineense, A. falcatus, Ficus sur and Croton macrostachyus) is in problem. In HG from all species $C$. arabica, $C$. papaya and Annona senegalenis is species with promising future. But abnormal distribution of $M$. indica and Persea americana with poor lower diameter class species were observed.

When we see the overall population structure of woody species which are grown in the both agroforestry practices, abnormal structure were observed. This is due to human interferences the growth and the densities of undergrowth woody species were affected. This may minimize the number of lower diameter class woody species which are grown in the land uses. In addition to this, in order to produce suitable environment for the growth of major species (e.g. Coffee), the regeneration and density of other species were affected by human activity.

\section{Conclusion}

The overall woody species diversity of the studied land uses was different from each other. Highest woody species diversity was recorded in the natural forest. From the two 
agroforestry practices, homegarden was conserves higher woody species diversity than shade grown coffee agroforestry practice. In the case of shade grown coffee agroforestry practice due to farmer's species selection for shade purpose, selective tree thinning and intensive human interference or management shade tree species diversity are less in number. Low species similarly in species compositions were observed among the three land uses. Generally, there is significant difference among natural forest, shade grown coffee agroforestry practice and homegarden agroforestry practice in woody species diversity composition.

\section{Acknowledgements}

The work was financed by Oromia Agricultural Research Institute, Sinana Agricultural Research center.

\section{References}

[1] Sayer, J., Chokkalingam, U. and Poulsen, J. (2004) The Restoration of Forest Biodiversity and Ecological Values. Forest Ecology and Management, 201, 3-11. http://dx.doi.org/10.1016/j.foreco.2004.06.008

[2] Food and Agriculture Organization (FAO) (2001) Global Forest Resources Assessment 2000. Main Report. FAO Forestry Paper 140, 479 p.

[3] Khumalo, S., Chirwa, P.W., Moyo, B.H. and Syampungani, S. (2012) The Status of Agrobiodiversity Management and Conservation in Major Agroecosystems of Southern Africa. Agriculture, Ecosystems and Environment, 157, 17-23. http://dx.doi.org/10.1016/j.agee.2012.01.028

[4] International Center for Research in Agroforestry (ICRAF) (2002) What Is Agroforestry? World Agroforestry Center, Nairobi.

[5] Kabir, M.E. and Webb, E. (2008) Can Homegardens Conserve Biodiversity in Bangladesh? Biotropica, 40, 95-110.

[6] Tolera, M., Asfaw, Z., Lemenih, M. and Karltun, E. (2008) Woody Species Diversity in a Changing Landscape in the South-Central Highland of Ethiopia. Agriculture, Ecosystems and Environment, 128, 52-58. http://dx.doi.org/10.1016/j.agee.2008.05.001

[7] Yakob, G. (2011) Diversity and Management of Woody Species in Homegarden Agroforesty in Gimbo Woreda, South West Ethiopia. Unpublished MSc Thesis, Hawassa University, Wondo Genet College of Forestry and Natural Resources, Hawassa, 82 p. http://www.worldagroforestrycentre.org

[8] Travis, I. and Adel, Y. (2010) Managing Shade Trees for Coffee Can Benefit the Soil.

[9] Negash, M., Starr, M. and Kanninen, M. (2013) Allometric Equations for Biomass Estimation of Enset (Ensete ventricosum) Grown in Indigenous Agroforestry Systems in the Rift Valley Escarpment of Southern-Eastern Ethiopia. Agroforestry System, 87, 571-581. http://dx.doi.org/10.1007/s10457-012-9577-6

[10] Didita, M. and Mengistu, B. (2012) The Role of Home Garden Agroforestry in Plant Diversity Conservation in Bale. In: Tadesse, W., Desalegn, G. and Yirgu, A., Eds., Forestry and Forest Products. Technologies and Issues, Ethiopian Institute of Agricultural Research, Addis Ababa, 1-14.

[11] Lulekal, E., Kelbessa, E., Bekele, T. and Yineger, H. (2008) Plant Species Composition and Structure of the Mana Angetu Mosit Montane Forest, South-Eastern Ethiopia. Journal of 
East African Natural History, 97, 165-185. http://dx.doi.org/10.2982/0012-8317-97.2.165

[12] Central Statistics Authority (CSA) (2012) Population and Housing Census: Administrative Report. Addis Ababa, 117 p.

[13] Institute of Biodiversity Conservation (IBC) (2005) National Biodiversity Strategy and Action Plan. Government of the Federal Democratic Republic of Ethiopia, Addis Ababa, 103 p.

[14] Lu, X., Xia, J. and Jang, J. (2010) Diversity and Composition of Understory Vegetation in Tropical Seasonal Rainforest of Xishuangbanna, Southwest China. International Journal of Tropical Biology, 59, 455-463.

[15] Jiangshan, L., Xiangcheng, M., Haiba, R. and Keping, M. (2009) Species-Habitat Associations Change in Subtropical Forest of China. Journal of Vegetation Science, 20, 415-423. http://dx.doi.org/10.1111/j.1654-1103.2009.01065.x

[16] Segura, M., Kanninen, M. and Suarez, D. (2006) Allometric Models for Estimating Aboveground Biomass of Shade Trees and Coffee Bushes Grown Together. Agroforestry System, 68,143-150. http://dx.doi.org/10.1007/s10457-006-9005-x

[17] Breitenbach, F.V. (1963) The Indigenous Trees of Ethiopia. 2nd Edition, Ethiopian Forestry Association, Addis Ababa, 306 p.

[18] Kelecha, W.M. (1980) A Glossary of Ethiopian Plant Names. 3rd Edition, Addis Ababa, 262 p.

[19] Mooney, H.F. (1963) A Glossary of Ethiopian Plant Names. Dublin University Press Ltd., Dublin, $79 \mathrm{p}$.

[20] Bekele, A. (2007) Useful Trees and Shrubs for Ethiopia, Identification, Propagation and Management for 17 Agroclimatic Zones. RELMA in ICRAF Project, Nairobi, 552 p.

[21] Clarke, K.R. and Warwick, R.M. (2001) Change in Marine Communities: An Approach to Statistical Analyses and Interpretation. 2nd Edition, PRIMER-E, Plymouth, 172 p.

[22] Krebs, C.J. (1999) Ecological Methodology. 2nd Edition, Benjamin Cummings, Menlo Park, $620 \mathrm{p}$.

[23] Magurran, A.E. (1988) Ecological Diversity and Measurement. Springer, Berlin, 354 p. http://dx.doi.org/10.1007/978-94-015-7358-0

[24] Kent, M. and Coker, P. (1992) Vegetation Description and Analysis: A Practical Approach. CRC Press, Boca Raton, 363 p.

[25] Diserud, O.H. and Odegaard, F. (2006) A Multiple-Site Similarity Measure. Biology Letters, 3, 20-22. http://dx.doi.org/10.1098/rsbl.2006.0553

[26] Moreno-Casasola, P., Mata, D.I., Madero-Vega, C., Castillo-Campos, G. and Warner, B.G. (2011) Floristic Composition and Soil Characteristics of Tropical Freshwater Forested Wetlands of Veracruz on the Coastal Plain of the Gulf of Mexico. Forest Ecology and Management, 262, 1514-1531. http://dx.doi.org/10.1016/j.foreco.2011.06.053 
Submit or recommend next manuscript to SCIRP and we will provide best service for you:

Accepting pre-submission inquiries through Email, Facebook, LinkedIn, Twitter, etc. A wide selection of journals (inclusive of 9 subjects, more than 200 journals)

Providing 24-hour high-quality service

User-friendly online submission system

Fair and swift peer-review system

Efficient typesetting and proofreading procedure

Display of the result of downloads and visits, as well as the number of cited articles

Maximum dissemination of your research work

Submit your manuscript at: http://papersubmission.scirp.org/

Or contact nr@scirp.org 